INTERNATIONAL DESIGN CONFERENCE - DESIGN 2018

https://doi.org/10.21278/idc.2018.0548

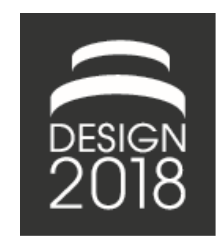

\title{
INDUSTRY-LED CORPORATE START-UP ACCELERATOR DESIGN: LESSONS LEARNED IN A MARITIME PORT COMPLEX
}

\author{
C. Garcia-Herrera, M. Perkmann and P. R. N. Childs
}

\begin{abstract}
Given the increasing disruption in every industry, firms can design new interfaces to further their strategic exploration efforts in order to remain competitive. Based on an inductive multi-case study research in a leading maritime port complex, we devised an actionable framework to design and run an industry-led accelerator through four steps: ecosystem orchestration, innovation funnel generation, flexible matching and scaling corporate start-up recurrent engagement. This framework can guide managerial practice and inform corporate start-up acceleration design in similar industrial contexts.
\end{abstract}

Keywords: organisation of product development, innovation management, entrepreneurship, lean product development

\section{Introduction}

Several sectors and industries around the world are experiencing pressure to adapt to new environmental conditions: disruptive technologies and AI, changing consumer needs, energy transition, digitalization, new regulatory standards, global competition (e.g. China). Whether it is food, finance, insurance, health, logistics, energy, cities or ports, companies operating in these sectors have started to jointly establish new approaches to collectively accelerate entrepreneurial innovation to cope with those unprecedented challenges. One of these new approaches is the industry-led corporate accelerator.

Being large and successful at one point in time is no guarantee of continued firm survival (O'Reilly and Tushman, 2013). A McKinsey study of the life span of firms in the S\&P 500 showed that in 1935, the average company was 90 years and that by 1975, that number had fell to 30 years. In 2005 it was estimated to be only 15 years (Foster and Kaplan, 2001). Several organizational designs have been implemented to cope with this survival challenge: R\&D units, Innovation Divisions, Corporate Venture Units, ambidextrous teams and, more recently, Open Innovation programs (Chesbrough, 2003; West et al., 2014). One of such newest designs is the corporate accelerator (Heinemann, 2015; Kohler, 2016) All these structures are designed to increase the innovativeness of corporations, which is the single most important predictor of long-term survival. Distinctively, corporate accelerators are lightweight, relatively non-expensive and easy-to-implement units that present new opportunities for executives who want to stimulate innovation inside the corporation or within a sector. However, they also present important challenges as to how to integrate these initiatives into the core strategic roadmap of large firms. (Weiblen and Chesbrough, 2015)

Since 2005, we have witnessed the global proliferation of accelerators-such as Y Combinator and Techstars - aimed at creating independent start-up companies: there are approximately 579 seed accelerator programs worldwide, which have invested approximately USD $\$ 206,740,005$ in 11,305 start-ups, according to existing indicators (Gust, 2016). Picking up this idea and the lean 
entrepreneurship practice (Ries, 2011; Blank and Dorf, 2012), large corporations have sought to benefit from entrepreneurial innovation by setting up corporate accelerators, which are built similarly to provide a "start-up" context, yet operate largely within the confines of the organization. The corporate accelerator is a new organizational interface aimed to unleash intrapreneurship (Antoncic and Hisrich, 2001; Parker, 2011; Shane, 2012) in large incumbent firms as well as to increase the exploration speed through experimentation with new business models, technologies and start-ups outside the core-but bound by the strategic objectives - of the firm. These interfaces within firms are designed to enable bottom-up and outside-in innovation to create sustainable new businesses, sometimes by inviting or mentoring external entrepreneurs.

Many corporations today have established accelerators, yet research has only began to examine how they function, and this is the first attempt to establish validated best practices, especially for a promising model: the industry-led accelerator. There are approximately 100 active corporate accelerators (Heinemann, 2015). 33\% of the European Accelerators are currently either run or supported by corporates (Bannerjee et al., 2016). In recent surveys, $88 \%$ of corporates declare that start-ups are 'essential to innovation strategy' (KPMG, 2016). In addition, the main trend in the start-up seed acceleration model is precisely the growing ties between accelerators and corporations.

\section{Methodology and data sources}

This paper is based on an ongoing inductive theory-building and framework-design multi-case research conducted in a leading European port maritime complex. Investigating a poorly understood, dynamic, under-theorized and temporal phenomenon like corporate accelerator design calls for an inductive research design (Strauss and Corbin, 1990). The main research question is the following: How do industry-led accelerators enable start-ups to engage with value chain incumbents and thus, orchestrate ecosystem value creation? To address this question, this paper uses an inductive theory building multicase study research (Eisenhardt, 1989; Yin, 1994) with three embedded units of analysis: i) the startups, ii) the accelerator and iii) the large firms co-funding the accelerator. We follow an opportunistic and flexible data-driven approach, which will advance theory based on systematic iterative dialogue with the cases, which we have been studying for over a year.

We conducted extensive interviews with the industry-led accelerator staff, the value chain incumbents, accelerated start-ups of both 2016 and 2017 cohorts, and other stakeholders of the emerging port-based entrepreneurial ecosystem. We triangulated semi-structured interviews with archival data and participant observation in training and mentoring interactions, roadshows, demo days, selection days, and advisory board meetings (see Table 1). We use the pseudonyms OceanAccel to refer to this industryled accelerator. We also use different pseudonyms to refer to the value chain incumbents and accelerated start-ups in this major European Port complex.

Table 1.

\begin{tabular}{|l|l|}
\hline DATA SOURCE & NUMBER \\
\hline Archival & 15 \\
\hline Semi-Structured Interviews & 40 \\
\hline $\begin{array}{l}\text { Observations of Scouting, Training, Mentoring Sessions, Advisory } \\
\text { Board, Roadshows at Corporates }\end{array}$ & 12 \\
\hline
\end{tabular}

\section{Models of corporate entrepreneurial acceleration}

Although a relatively recent organizational phenomenon, there is already relevant differentiation to date in terms of the accelerators' design, governance and functions. Fuelled by the global proliferation of seed accelerators and lean entrepreneurship practice, corporations have set up either internal, hybrid or industry-led accelerators, superseding more traditional ways of promoting innovation and entrepreneurship through internal corporate innovation or corporate venture units. Based on the type of mentoring, networking, resources, deal, firms' and industrial ecosystem's involvement, our research has identified four (4) main models of corporate accelerators, as showed in Table 2. 
Table 2. Elements of each corporate entrepreneurial accelerator model

\begin{tabular}{|c|c|c|c|c|}
\hline & $\begin{array}{l}\text { Exclusive } \\
\text { in-house }\end{array}$ & Hybrid in-house & $\begin{array}{l}\text { "Powered by" } \\
\text { (Franchised) }\end{array}$ & Industry-led \\
\hline Selection & $\begin{array}{l}\text { Only internal } \\
\text { projects initiated } \\
\text { by employees }\end{array}$ & $\begin{array}{l}\text { Internal projects } \\
\text { and external } \\
\text { start-ups }\end{array}$ & $\begin{array}{l}\text { External start-ups } \\
\text { jointly scouted and } \\
\text { mentored by firm } \\
\text { and accelerator }\end{array}$ & $\begin{array}{l}\text { External start-ups } \\
\text { collectively scouted, } \\
\text { selected and mentored }\end{array}$ \\
\hline $\begin{array}{l}\text { Mentorship by VPs, C-level } \\
\text { and R\&D + i executives }\end{array}$ & $\sqrt{ }$ & $\sqrt{ }$ & $\sqrt{ }$ & $\sqrt{ }$ \\
\hline $\begin{array}{l}\text { Networking with investors } \\
\text { and ecosystem key players }\end{array}$ & & & $\sqrt{ }$ & $\sqrt{ }$ \\
\hline $\begin{array}{l}\text { Fixed short-term \& cohort- } \\
\text { based programs between } 3 \text { - } \\
6 \text { months }\end{array}$ & $\sqrt{ }$ & $\sqrt{ }$ & $\sqrt{ }$ & $\sqrt{ }$ \\
\hline Provide stipends $(15 \mathrm{~K}-50 \mathrm{~K})$ & & & $\sqrt{ }$ & $\sqrt{ }$ \\
\hline $\begin{array}{l}\text { Take a non-controlling } \\
\text { equity }(\mathrm{b} / \mathrm{w} 6 \% \text { and } 8 \% \text { ) }\end{array}$ & & $\sqrt{ }$ & $\sqrt{ }$ & $\sqrt{ } *$ \\
\hline Funded by one corporate & $\sqrt{ }$ & $\sqrt{ }$ & $\sqrt{ }$ & \\
\hline $\begin{array}{l}\text { Objectives derived from } \\
\text { companies' strategic } \\
\text { challenges }\end{array}$ & $\sqrt{ }$ & $\sqrt{ }$ & $\sqrt{ }$ & \\
\hline $\begin{array}{l}\text { Objectives driven by } \\
\text { collective shared vision or } \\
\text { industrial challenges }\end{array}$ & & & & $\sqrt{ }$ \\
\hline Examples & $\begin{array}{l}\text { BMW's } \\
\text { Accelerator, ING's } \\
\text { Innovation Studio } \\
\text { and UBS' } \\
\text { Innovation Lab }\end{array}$ & $\begin{array}{l}\text { Telefónica's } \\
\text { Wayra and } \\
\text { Airbus' Bizlab }\end{array}$ & $\begin{array}{l}\text { Barclays', Shell's } \\
\text { Microsoft's and } \\
\text { Disney's corporate } \\
\text { accelerators }\end{array}$ & $\begin{array}{l}\text { PortXL, HighTechXL } \\
\text { AIA-Konica Minolta } \\
\text { Digital Health Accelerator } \\
\text { Logistics Accelerator by } \\
\text { Kaleido, Lufthansa Cargo, } \\
\text { MAN and Fiege. }\end{array}$ \\
\hline
\end{tabular}

* There are a few exceptions

Source: own elaboration partly based on Heinemann, 2015

\subsection{The industry-led corporate start-up accelerator}

When uncertainty, technology or unprecedented change - think new regulatory frameworks, energy transition, digitalization, AI or sustainability challenges - affect a sector, an industry-led accelerator can be an effective tool to co-create solutions to key industrial and firm-level challenges by attracting entrepreneurial talent and leveraging collective intelligence (Malone et al., 2010)

If the above sets the overall context, the key strategic question at the firm level is still the following: why should a firm co-fund or join an industry-led accelerator instead of setting an internal exclusive one fully aligned with its core strategy?

Our research has uncovered three main reasons: i) to be more effective and comprehensive in the scouting of new technologies and business models, ii) to learn from entrepreneurial innovation, that is, from startups' lean and agile processes aimed at quick validation of new business propositions and new technologies, iii) to get inspiration to fuel internal innovation initiatives and unleash the intrapreneurial spirit.

How does the industry-led accelerator specifically create value for its corporate partners and industry at large? First, by organizing a collective vision about the challenges facing the industry. Although each company might have its own frames and interpretation of key challenges going forward, an industry-led accelerator can put forward a collective vision, advance it and create ecosystem momentum. Second, an industry-led accelerator creates value by bringing external generative innovation that can complement firm-level digital innovation and modular requirements. That is, this type of accelerator creates a funnel for innovation supply pull based on broadly specified ecosystem-level and firm-level challenges. Third, bidirectional fit and flexible matching create value for each corporate partner. The industry-led accelerator scouts innovation inputs (start-ups and scale-ups) based on the ecosystem's general challenges and broadly 
defined firms' needs. Therefore, the accelerator enables bidirectional fit, that is, it scouts and selects startups, which value propositions' meet the problem domain of corporate partners or relevant stakeholders in the industrial ecosystem. To enable problem-solution fit, the industry-led accelerator pushes forward a flexible matching approach, that is, start-ups can broadly search for a match within the industrial ecosystem: start-ups are not allocated to a fixed corporate partner to validate its business model, rather they get the chance to explore different corporate partners to engage with and hopefully do business with during the 3-month programme. In this model of ecosystem acceleration, start-ups and scale-ups can further validate their propositions and actually end up engaging with more than one partner, even with competitors in an industry. Finally, to capture the value of entrepreneurial innovation - processes, inspiration, ideas - that has been scouted, selected and mentored within the industrial ecosystem, corporates need to set-up new internal process and re-organize their R\&D and innovation functions.

The main two differences of the industry-led accelerator are funding and objectives. As showed above in Table 2, funding usually comes from a group of large firms - sometimes even competitors - or a public-private consortia guided by a shared vision of key challenges and opportunities facing a sector or a region. Our research has showed that it is easier and sustainable in the long run when there are no competitors in the joint industrial effort. However, provided there is a long-term cooperative agreement - usually between 3 and 5 years - competitors can also participate together in an industryled accelerator. In the case of OceanAccel, one corporate partner in the tank storage services explicitly requested exclusivity while two competitors in the dredging business decided to join it, which evidenced the industrial collaborative approach of this type of accelerator.

Table 3. Structural elements for industry-led corporate start-up accelerator design

\begin{tabular}{|c|c|}
\hline Structure & Description/Number \\
\hline Type of Organization & Usually a Non Profit that may or may not have for-profit subsidiaries \\
\hline Business Model & Corporate Funding and Governmental/City/Region Funding. \\
\hline Governance & $\begin{array}{l}\text { Board, including representatives of corporate partners, reputable public } \\
\text { figures and industry stakeholders }\end{array}$ \\
\hline Duration of Program & 3 months plus 100 days of contracts \& deals follow-up \\
\hline Start-up Deals & $\begin{array}{l}\text { Convertible Note or } 8 \% \text { equity, whose potential returns will be later re- } \\
\text { invested into the program. There are also only-program commitment options. }\end{array}$ \\
\hline Corp Partners Founders & At least two non-competitors \\
\hline $\begin{array}{l}\text { Main Value Proposition } \\
\text { for Start-ups }\end{array}$ & $\begin{array}{l}\text { Direct access to launching customers; Active support by mentors; Office } \\
\text { space for six months; Extensive program on business model, finance, } \\
\text { investment, pitching and deal making; between USD15K-USD\$50K as } \\
\text { compensation for housing, food and services. }\end{array}$ \\
\hline $\begin{array}{l}\text { Value Proposition for } \\
\text { Corporates }\end{array}$ & $\begin{array}{l}\text { Technology scouting; Start-ups' roadshows to inspire and fuel internal } \\
\text { innovation; Help to bridge organizational silos; Participation in the Advisory } \\
\text { Board to 'steer' the accelerator to key needs; problem-solving through proof- } \\
\text { of-concepts and pilots }\end{array}$ \\
\hline $\begin{array}{l}\text { Value Proposition for the } \\
\text { Industry and/or Region }\end{array}$ & $\begin{array}{l}\text { Bring Innovation and generativity to a sector; develop an industrial } \\
\text { architecture; attract entrepreneurial talent to an Industry/Region/City }\end{array}$ \\
\hline
\end{tabular}

Source: own elaboration based on current industry-led accelerators structures

This model of accelerator is usually a non-profit but can also operate under a mixed model with forprofit subsidiaries that governs the deals with every start-up cohort. Its governance depends on a Board, comprising partners firms' C-Level executives, serial entrepreneurs, angel investors, VCs and/or Banks and reputable public figures. At least two corporate or public entities are required from the outset to 
launch and support the industry-led accelerator and thus, to create ecosystem's momentum or even to create a de novo industrial ecosystem.

This industry-led accelerator's value proposition is twofold. On the one hand, start-ups get direct mentoring access to first corporate customers, who help shape and customize solutions to the particular needs and pains of the ecosystem's players in addition to more standardized resources (training, office space, living stipend for 3 months). On the other hand, large firms do technology scouting and have the chance to participate in the shaping and steering of the industrial ecosystem by selecting start-ups and scale-ups that fit. In addition, large companies address problems through proof-of-concepts and solution pilots with start-ups and, in turn, get inspired and learn from lean start-up processes to fuel internal innovation and unleash the intrapreneurial spirit.

\section{Designing effective industry-led accelerators in four steps}

Our research has devised four actionable steps to orchestrate both value creation and capture for both corporates and start-ups through an industry-led corporate accelerator. Our normative framework inducted from practice can be used in different sectors and geographies, following the four steps described below. We believe this framework - Figure 1 - can be of particular relevance for industries biased to operational efficiency and a limited innovation track record.

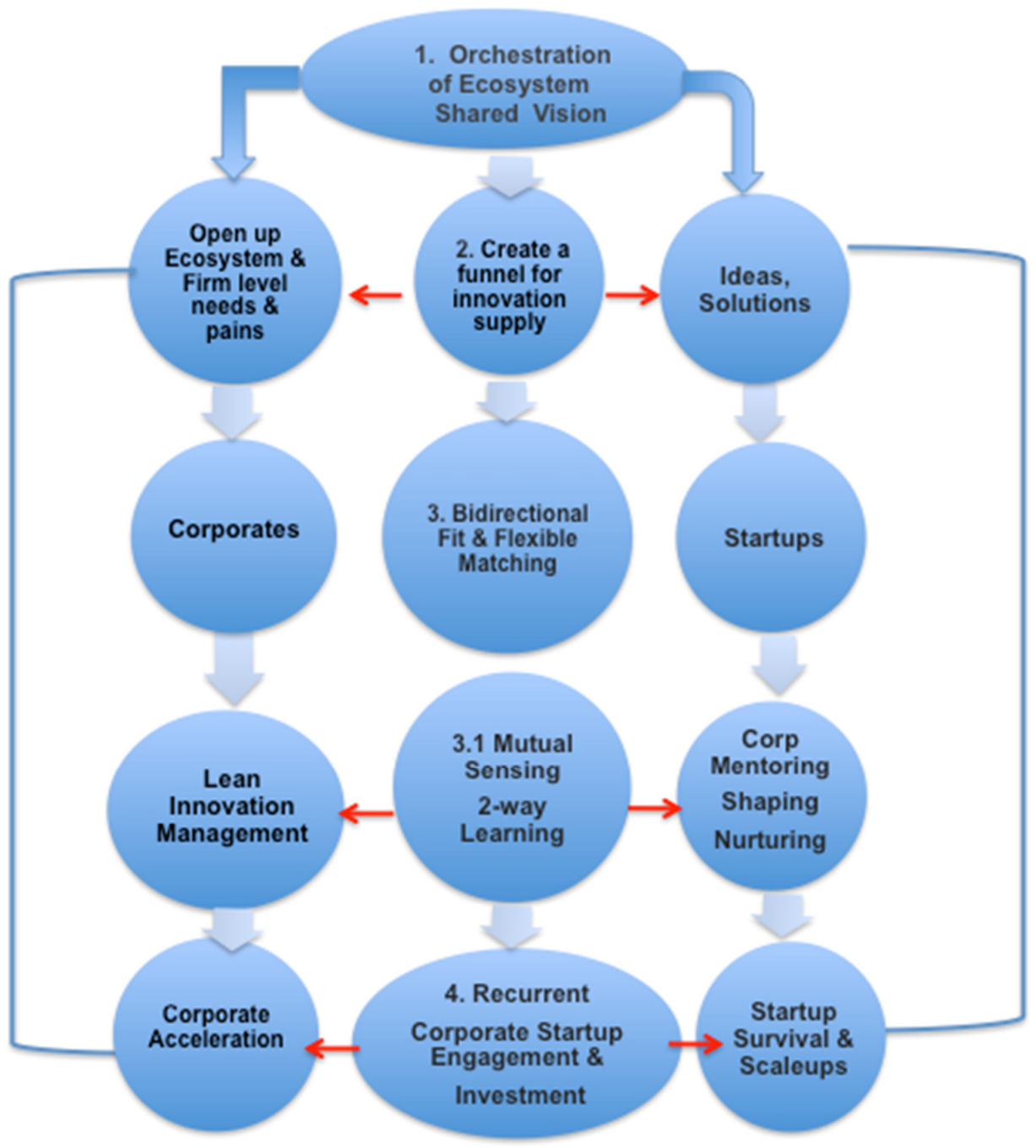

Figure 1. Actionable framework for corporate start-up acceleration 


\subsection{Create a funnel for generative innovation supply pull based on the industrial ecosystem broad challenges and corporate needs}

One of the initial key issues to address when planning to launch an industry-led accelerator in a value chain is how does the system get momentum to collectively enact a shared vision and action.

Our research shows that in the very early stages of convincing value chain players to co-launch and cofund an industry-led accelerator, the role of ambidextrous C-suite executives (Tushman et al., 2011) is critical in both the symbolic and material support. In the case of OceanAccel, it was the European Port Authority's Chief Financial Officer who played a pivotal role in taking the first step to set a shared vision and to trigger the value chain's key players to join the innovation journey even when the road ahead was not clear. This European Port's CFO recalls how the new entrepreneurial ecosystem got started: "In hindsight, it seems very structured but when I was starting, I was finding my way through the fog (...) My first step in 2012 was a 3-hours meeting in a boat with 15 CEOs and Board Directors where we asked ourselves 'Do we want to innovate, why, should we? The outcome was that there is indeed a need in the port but also that we should not copy other regions." This collective visioning exercise was complemented by a strategic roadmap set forth in the Port Vision 2030 document (Port of Rotterdam Authority, 2011). The shared vision, the journey and the industry-led accelerator have to be uniquely authentic to attract talent, gain legitimacy and, ultimately, make a difference in the global industry. In the case of OceanAccel, it had to find its 'own way', not the Silicon Valley one.

The shared vision towards a new industrial architecture (Jacobides et al., 2006) is not enough to enable the transition from a vertically integrated value chain of stand-alone firms to an industrial entrepreneurial ecosystem, where value creation and capture across different boundaries start to take place. Rather, one of the key initial functions of an industry-led accelerator is to generate a funnel for continuous incoming external innovation to address needs at both the ecosystem-level (sustainability, gas emissions, port scheduling, value chain digitalization, etc.) and at the firm-level (equipment maintenance, operators training, productivity, compliance to regulations, etc.)

An industry-led accelerator creates value by bringing external generative innovation that can contribute to solve value chain challenges as well as to complement firm-level innovation and modular requirements. That is, this type of accelerator creates a funnel for innovation supply pull based on broadly specified ecosystem-level and firm-level challenges. This approach resembles the new generation of open innovation research (Chesbrough, 2003), which has recently moved beyond the dyadic interaction between two firms, to collaborations with external networks, platforms, ecosystems and communities (Vanhaverbeke, 2006; West and Gallagher, 2006; West and Lakhani, 2008).

\subsection{Ensuring bidirectional fit through flexible matching and mutual sensing}

Our research suggests that the industry-led corporate accelerator requires a good degree of transparency of the value chain challenges and corporates' pains to enable fit with incoming incremental, architectural or radical innovation (Henderson and Clark, 1990) streams that are scouted and selected. To enable 'fit' between the funnel and corporates, a minimum level of trust and openness is needed in the industrial ecosystem. There are two critical bidirectional activities to be performed: mutual sensing and flexible matching. Corporates who decide to participate in an industry-led accelerator need to fulfil two conditions. First, they need to know across organizational levels what their latent and emerging problems are. It is not trivial to really know what is going on at different levels of an organization, as a former HP's CEO once famously put it: If HP knew what it actually knows, HP would be three times more profitable (cited in Davenport and Prusak, 1998). Second, they need to open-up these problem domains so the accelerator can scout and select incoming innovation streams accordingly, and later - during the program - allow start-ups to quickly search inside the corporates to validate their problems hypotheses and then match with their customizable solutions. Therefore, mutual sensing takes place: on the one hand, corporates sense problems internally and collect those use cases to present to potential solvers: the start-ups. On the other hand, startups once selected into the program search within those use cases and across organizational levels to narrow down their search and match possibilities. Sensing, then, works both ways.

An industry-led accelerator operates based on flexible matching. That is, selected start-ups can validate and match their solutions with more than one corporate partner. Therefore, flexible matching facilitates scalability within the focal value chain in that corporates do not expect exclusive work with a particular 
start-up. Rather, through mentoring they promote engagement with different stakeholders, including the accelerators' partners and other stakeholders in the emerging industrial ecosystem. Start-ups, then, do establish proof-of-concepts and pilots contracts with different industrial players. Flexible matching increases the odds of recurrent and scalable engagement within the focal ecosystem and later in other networked industrial ecosystems.

Successful bidirectional fit and flexible matching are based on the following core activities to be performed by the industry-led accelerator in collaboration with its corporate partners: local and global sourcing; co-selection of non-competing start-ups, including ones $(20 \%)$ with radical innovation business propositions as well as early-stage start-ups that can broadly search - and experiment with their business model - within the focal industrial ecosystem.

Local and Global Sourcing: to unlock the entrepreneurial spirit in operational efficiency-oriented industries, it is fundamental not only to have a shared vision but also a global outlook. It is imperative to bring external generative innovation streams into the current industrial architecture to shape its future. As OceanAccel's Managing Director put it, "though this is a renowned European hub and almost everyone speaks English, it is still in many senses, too locally and inward-looking. That's why we need to bring the best start-ups of the world here." That inward-looking outlook is the case in several industrial milieus around the world, with only a few exceptions of global hubs such as Silicon Valley, the Boston corridor, London and Singapore. To achieve this global outlook, OceanAccel both scouts and selects start-ups using a ratio of $20 \%$ to $80 \%$ between local and overseas ventures.

To allow a seamless flexible matching, it is required not only global sourcing but also selection of noncompeting start-ups that can be shaped and nurtured through ongoing corporate mentoring. Therefore, two type of ventures can and should be selected in an industry-led accelerator: early-stage ventures that can broadly search and at the same time be shaped by the ecosystem's corporate players, as well as scale-ups that can directly engage with these players. Industry-led accelerators share one key condition to enable ventures' growth: the readiness and willingness of the industrial partners not only to mentor entrepreneurs but also to do business with them.

Client discovery within the industrial ecosystem starts during selection days. Corporates already know about the initial value proposition of the incoming start-ups. Therefore, corporate start-up engagement implicitly begins during the selection process through initial exploration of proof-of-concepts. As the $\mathrm{COO}$ of UK venture Maritime Monitor, explains: "An initial agreement to work in the tank facilities of the Port of Amsterdam was established during the selection days". This initial contact allows establishing a baseline, from where search for a problem-solution fit will take place during the official acceleration process. Corporates also learn and get inspired by start-ups during the selection process. As the Director of Digital Innovation of a 400 years-old Dutch tank storage company puts it: "Starting on the very selection days, we work with start-ups exploring proof-of-concepts within the domain of our collected use cases as these entrepreneurs are open to look at problems and they do not want to push a solution and just sell licenses...in a way, it is easier to work with a start-up than with an IBM." Even in efficiency and safety-driven industries such as the maritime one, senior leadership of large incumbents are realizing the value of working with and learning from start-ups.

The selection of non-competing start-ups ensures that business model search can happen without enough pressure for access to the industrial ecosystem's resources, thus enabling both flexible matching with corporates and peer learning among the selected entrepreneurs. This selection has one additional condition: the selection of start-ups that can search for business model and industrial fit. Contrary to the idea that accelerators need to select and invest only in start-ups with a very clear value proposition and ex-ante product-market fit, our research suggests otherwise. Because start-ups are validating their business models within a specific industrial ecosystem, it is desirable to have a value proposition flexible enough to be shaped and customized according to the needs of the ecosystem's players. Start-ups offering solutions based on generative mainstream technologies such as drones, virtual and augmented reality are shaped during the acceleration program in order to address the needs of one or more players, which were not completely transparent at the outset. On the opposite, if start-ups come with a rigid business model, the industrial shaping and pivoting are reduced and thus, chances of product-market fit failure, increase.

Two examples from OceanAccel's 2016 start-ups cohort illustrate this mechanism at work. On the one hand, AquaWave started as a promising multi-sensor autonomous platform over a drone with 10 
functionalities but during the acceleration program and thanks to key corporate mentors from different companies, they realized their intended solution was "too complex, too expensive to develop and with too much risk". Instead, AquaWave pivoted and then focused on-just-one functionality: jetty inspections. Then it managed to do a pilot with one of the main accelerator's corporate partners during the remaining of the program. Interestingly enough, the same Corporate Director of this pilot contract who had referred to this inspection technology start-up as being "a lot of everything is a lot of nothing" finally agreed to be its very first customer. Initial industrial search turned into problem-solution fit through just in time mentoring by key ecosystem players.

On the other hand, PortGateway, a port scheduling start-up with an operating cloud-based service and valid product-market fit in the U.S. and Sweden, was not able to adjust its value proposition to the Port of Rotterdam ecosystem or to customize its technology to the major European port. The PortGateway's founder recalls this situation: "I wish I had been exposed to the accelerator earlier in the process. I do not have a lot of room to change direction at the moment. I am still flexible and agile, but I have customers and capabilities that have to maintain and deliver. Had I previously known what I learned in OceanAccel I might have done thing differently from the beginning." In certain circumstances, not being able to agilely change course of action in both the business model and the underpinning technology might result in customer development failure.

\subsection{How to join and leverage an industry-led accelerator}

As a corporate, it takes leadership and commitment of resources - especially time - to join and capture value through an industry-led accelerator. The key question is then: How do you set up internal processes and practices to both create and capture value through the industry-led accelerator?

This type of accelerator does not only validate start-ups within the focal industrial milieu but also performs a fundamental action: it uses start-ups to inspire, update and try to accelerate corporate innovation processes. To be able to do this, start-ups need to engage not only with corporate staff at different levels but also with the corporate innovation process itself.

How do managers and entrepreneurs alike enable this engagement process? First, a shared semantic is needed to agree upon, visualize and measure the innovation process. OceanAccel and its corporate partners uses the demo, proof-of-concept, pilot, implementation and scale semantic that everyone in the Port industrial entrepreneurial ecosystem understand. A demo is the presentation of what a certain value proposition or start-up technology is capable of doing outside the implementation context; a proof-ofconcept is a demonstration in the actual corporate context of such start-up solution during a very limited time period that ends with an assessment; a start-up pilot is a full innovation project paid for and implemented at the business unit, which at this point takes control over it. After the successful evaluation of a pilot, the start-up's technology can be fully deployed, scaled and orbited within the focal ecosystem. These progressive validation steps enable industrial engagement with external incoming innovation streams previously scouted and selected. The demo/proof-of-concept/pilot/implementation/scale framework provides a shared language to allocate corporate resources, engage with external explorative innovation streams as well as to assess start-up progress, success and overall impact. Industry-led accelerators should develop along with corporate partners and relevant stakeholders a dashboard to monitor corporate start-up engagement over time.

In the case of a 400 years-old tank storage company that decided to join the accelerator due to digitalization challenges, it has developed a new innovation process. This innovation process starts with the collection of business challenges in port terminals. Then, it looks for start-ups and R\&D institutes in the industrial entrepreneurial ecosystem - including the accelerator - to address those challenges. If there is a match with a potential solver, a proof-of-concept is launched. As the Digital Innovation Director explains: "All proof-of-concepts are done with external parties. This comes back to OceanAccel...If you do or try to do the proof-of-concepts in-house, you immediately run into problems of resources, everybody is busy, and then these proof-of-concepts will take forever..." This open innovation type-of-approach has several benefits, including time and resources saving, non-interference with daily operations as well as clear defined roles and responsibilities.

Corporates need to perform and sustain various internal actions to create momentum and set the stage for incoming external innovation streams. Then, actions are required to capture the value of engaging 
with these innovation streams. Even in corporate contexts where there is an innovation vision from senior leadership, several decision-layers and related delays exist when trying to engage with start-ups: from demo to a proof-of-concept to a pilot to, ultimately, scalable implementation roll-out. Usually these are not only delays but also rather actual chasms in the corporate innovation process, especially between proof-of-concepts, pilots and full rollouts. The decision and the budget are not clearly allocated among the corporate innovation unit and the business unit. At the end of the day, nobody is in charge to make the final decision and allocate the resources, accordingly. Start-ups, then, get stuck after the demo or proof-of-concept phase. Start-ups keep waiting and de-accelerate. The opportunity to solve a problem gets diluted. Why and what can we do about it?

By and large, large companies in efficiency-oriented industrial ecosystems use the stage-gate product innovation process (Cooper, 2008), which does not facilitate engagement with start-ups. This linear stage-gate process is useful to manage internal complexity but it is not effective to deal with external entrepreneurial innovation streams that are being mentored by the same people running the internal corporate innovation pipeline.

In the case of industry-led accelerators, a hybridization take place where the inside/outside border gets blurred: the internal problems become opportunities for the start-ups, which in turn, customize their value propositions to address those problems through corporate mentoring. There is engaged involvement of mentors to validate the start-ups' value propositions and to help them adapt their technology to solve pressing problems at the firm and industrial ecosystem level. This symbiotic engagement becomes incompatible with the linear stage-gate process still prevalent in several large incumbents. This stage-gate process can further delay the overall process by putting several decisionlayers that consume time and decrease start-ups' momentum.

Given the above, the question is: what can be done to manage this incompatibility and solve this speed differential in order to achieve better engagement with start-ups?

Joining an industry-led accelerator creates the conditions to speed up firm-level innovation processes and corporate entrepreneurship practices. Based on our research, we suggest the following actions to promote corporate entrepreneurial acceleration.

First, this is an opportunity for large companies to move away from traditional linear stage-gate models and start piloting new lean entrepreneurship practices with increased speed and room for experimentation. With this approach, large firms can reduce the cycle time of problem-identification, ideation, prototyping, validation/invalidation and implementation. The adoption of lean start-up methods by large firms is neither a straight nor an easy process given the corporate controls, existing decision-layers and established procedures. However, there are already useful guidelines to experiment and implement such new lean approaches in large enterprises (Blank and Newell, 2017; Ries, 2017). For example, OceanAccel's partner SatelliteX, a global dredging marine infrastructure firm is currently revamping its stage-gated innovation challenge process towards a faster, continuous and experimentation-oriented one that will involve all levels of the company to increase the dedication on radical innovation ideas. One of the new functions of SatelliteX's R\&D Department is precisely to scout and work with start-ups, which is another way to learn and adopt lean entrepreneurship practices. According to its General Manager for Corporate Research and Development, there are three reasons for this new function: "i) to identify new technologies and links for new opportunities, ii) to learn from the processes that start-ups go through while accelerating their businesses so we can apply it to our own initiatives, iii) to use the accelerator as a source of inspiration for our own colleagues." Through its participation in the accelerator, this company not only scouts new technology but also learns new acceleration practices to advance its innovation journey into the unknown. Second, senior executives and managers can try ambidextrous organizational designs, where at least one unit is released from operational pressure. These units can focus on far ahead projects, i.e., exploration of highly uncertain radical innovation opportunities, including proof-of-concepts with the accelerated startups on even apparently contradictory strategic goals (Smith and Tushman, 2005; Smith and Lewis, 2011). However, these units require support by senior leadership, who will then integrate those efforts into the overall strategic roadmap. For example, SatelliteX's R\&D Department reports directly to the Board of Directors, which provides autonomy to deal with contradictory goals and times-frames. Third, partner companies can send their internal teams to industry-led accelerators to learn first-hand the sense of urgency, experimentation and business validation tools of their own internal ventures. This is a common 
practice in several industry-led accelerators such as HighTechXL. For this practice to be successful, the corporate ventures to be selected should not compete with the external start-ups, which are being mentored at the same time by the corporate partners themselves.

\subsection{Scaling corporate start-up recurrent engagement}

As an equity holder, industry-led accelerators - and the firms backing it — have a legitimate interest in start-ups' survival and scalability. That is why this model of industry-led accelerators promotes a recurrent engagement in the focal industrial ecosystem, and tries to expand new external markets for alumni start-ups and scale-ups through their corporate partners' global presence.

If and after the pilot phase chasm is crossed, innovation implementation contracts can be scaled throughout the focal industrial ecosystem during the post-acceleration phase-which usually ranges from 100 to 160 days - to consolidate the business model, to get additional pilots and implementation contracts and thus, develop recurrent customers.

Due to digitalization, start-ups can then easily scale beyond the initial focal industrial ecosystem and address new global interconnected markets: 'If you make it here, you can do it in any port of the world', as one OceanAccel's start-up founder once put it. An industry-led accelerator enables the exploration of problem-solution fits in similar contexts by transferring the client discovery and validation process. The global presence of the accelerator' corporate partners can be a key gateway to successfully scale and achieve fit beyond the focal industrial ecosystem.

Finally, the corporate start-ups dynamics required to launch and sustain an industry-led accelerator can enable the transition from a vertically integrated value chain of stand-alone firms towards a horizontal entrepreneurial ecosystem that leverages both digital and spatial affordances (Autio et al., 2017). Such transition would be possible not only because of the horizontal knowledge sharing between start-ups and scale-ups but rather by the transformation of large value chain incumbents into active entrepreneurial agents that co-create value and realize innovations together with the new ventures.

\section{Towards a new corporate start-up acceleration model}

Given the increasing disruption and survival challenges in every industry, large firms can now experiment with a new organizational interface to further their strategic exploration efforts to remain competitive: the corporate accelerator. In this paper we have focused on one of the promising models: the industry-led corporate start-up one. Based on a revelatory maritime port complex, we have devised a framework to design an industry-led accelerator through four actionable steps.

Our research suggests that senior leadership from at least two corporate or public players is needed to enact a collective vision that embraces different value chain incumbents based on a ten to twenty years ahead shared horizon, comprising key opportunities and challenges. Then, the industry-led accelerator needs to address those opportunities and challenges by creating a funnel for external incoming entrepreneurial innovation streams. The accelerator and its corporate partners have to ensure good and best bidirectional fit between these streams and the challenges/opportunities at the firm and industrylevel. On the one hand, this requires the right scouting and sourcing of start-ups, and on the other, that these incoming external ventures need to search within the value chain to find problem-solution match as early as possible. This search and validation with incumbents operate under the flexible matching principle, i.e., start-ups can validate and pilot their solution with more than one corporate partner - even competitors - at the same time.

A successful industry-led accelerator operates under conditions of transparency and trust to allow problem search, attribution, aggregation, matching and monitoring over time. Governance of the accelerator is ensured through either a non-profit or mixed organizational model but usually with an advisory board, comprising key players of the industrial value-chain or emerging ecosystem, including industry, regulators, academia, serial entrepreneurs, banks and/or VCs. Acceleration is needed not only at the start-up level but also at the firm-level to revamp current innovation processes towards open, lean, flexible ones that enable speeding up and crossing the various corporate chasms and silos. Finally, horizontal knowledge sharing and spillovers are enabled by recurrent and scalable corporate start-up engagement both within and beyond the focal industrial ecosystem through the global presence and alliances of key players. 
We believe this model can inform managerial practice and policy-making in similar industrial contexts by orchestrating corporate start-up dynamics and thus, value creation and capture at the new venture, large firm and ecosystem level.

\section{Limitations and further research}

Given the under-theorized nature and absence of comprehensive datasets of the corporate accelerator phenomena, we chose an inductive approach to study in depth a revelatory research setting of a leading European maritime port complex, comprising the industry-led accelerator, the co-founding value chain incumbents and the accelerated start-ups. Though our framework, findings and actionable four steps are not generalizable to other settings, we think they can shed light on the basic operating principles needed to design, run and sustain a similar industry-led corporate start-up accelerator. Our objective was twofold in this paper: first, to advance knowledge in this new promising area where innovation studies, entrepreneurship research and design science intersect, and second, to provide guidelines and heuristics to inform managers who want to establish or re-design these new organizational interfaces to accelerate entrepreneurial innovation at the firm, industry and ecosystem level. Further research will analyze in greater detail the process by which start-ups successfully engage over time with large firms through industry-led accelerators to further validate our integrative framework and its actionable steps. Further research should also study industry-led corporate start-up acceleration dynamics in new similar industrial contexts to allow comparison, enable generalizability and ensure a parsimonious theory to inform corporate start-up acceleration design.

\section{Acknowledgements}

This paper is part of a $\mathrm{PhD}$ research project that is being supported by CONICYT's Becas Chile and the Research and Development Management Association (RADMA) in the UK. The first author wants to thank Petra BadkeSchaub for her invitation as a Guest Researcher to Delft University of Technology's Industrial Design Engineering, Product Innovation Management Department. The first author is also grateful for the notable research access granted by OceanAccel's staff, in particular, by Director Carolien Sanders and Managing Director Mare Straetmans, who believed in the practical insights of this project and have enabled the initial exploration of the dynamics of both corporate partners and start-ups in this leading industry-led accelerator.

\section{References}

Antoncic, B. and Hisrich, R.D. (2001), "Intrapreneurship: Construct refinement and cross-cultural validation", Journal of Business Venturing, Vol. 16 No. 5, pp. 495-527. https://doi.org/10.1016/S0883-9026(99)00054-3

Autio, E., Nambisan, S., Thomas, L.D.W. and Wright, M. (2017), "Digital affordances, spatial affordances, and the genesis of entrepreneurial ecosystems" Strategic Entrepreneurship Journal, Vol. 12 No. 1, pp. 72-95. https://doi.org/10.1002/sej.1266

Bannerjee, S., Bielli, S. and Haley, C. (2016), Scaling together: Overcoming barriers in corporate-startup collaboration, NESTA, London.

Blank, S. and Dorf, B. (2012), The Start-up Owner's Manual: The Step-By-Step Guide for Building a Great Company, K\&S Ranch, Pescadero.

Blank, S. and Newell, P (2017), What Your Innovation Process Should Look Like. [online] Harvard Business Review. Available at: https://hbr.org/2017/09/what-your-innovation-process-should-look-like

Chesbrough, H.W. (2003), Open Innovation: The New Imperative for Creating and Profiting from Technology, Harvard Business School Press, Boston.

Cooper, R.G. (2008), "Perspective: The Stage-Gate ${ }^{\circ}$ Idea-to-Launch Process-Update, What's New, and NexGen Systems", Journal of Product Innovation Management, Vol. 25 No. 3, pp. 213-232. https://doi.org/10.1111/j.1540-5885.2008.00296.x

Davenport, T.H. and Prusak, L. (1998), Working knowledge: How organizations manage what they know, Harvard Business School Press, Boston.

Eisenhardt, K.M. (1989), "Building theories from case study research", Academy of Management Review, Vol. 14 No. 4, pp. 532-550. https://doi.org/10.5465/AMR.1989.4308385

Foster, R. and Kaplan, S. (2001), Creative Destruction, Currency, New York.

Gust (2016), Global Accelerator Report 2016. [online] Gust. Available at: http://gust.com/accelerator_reports/2016/global/ 
Heinemann, F. (2015), Corporate accelerators: A study on prevalence, sponsorship, and strategy, Master of Science Thesis, MIT.

Henderson, R.M. and Clark, K.B. (1990), “Architectural innovation: The reconfiguration of existing product technologies and the failure of established firms", Administrative Science Quarterly, Vol. 35 No. 1, pp. 9-30. https://doi.org/10.2307/2393549

Jacobides, M.G., Knudsen, T. and Augier, M. (2006), "Benefiting from innovation: Value creation, value appropriation and the role of industry architectures", Research policy, Vol. 35 No. 8, pp. 1200-1221. https://doi.org/10.1016/j.respol.2006.09.005

KPMG (2016), New Horizons 2015: On the road to corporate startup collaboration, KPMG Advisory N.V., Amstelveen.

Kohler, T. (2016), "Corporate accelerators: Building bridges between corporations and start-ups", Business Horizons, Vol. 59 No. 3, pp. 347-357. https://doi.org/10.1016/j.bushor.2016.01.008

Malone, T.W., Laubacher, R. and Dellarocas, C. (2010), "The collective intelligence genome", MIT Sloan Management Review, Vol. 51 No. 3, pp. 21-31.

O'Reilly III, C.A. and Tushman, M.L. (2013), "Organizational Ambidexterity: Past, Present and Future”, Academy of Management Perspectives, Vol. 27 No. 4, pp. 324-338. https://doi.org/10.5465/amp.2013.0025

Parker, S.C. (2011), "Intrapreneurship or entrepreneurship?”, Journal of Business Venturing, Vol. 26 No. 1, pp. 19-34. https://doi.org/10.1016/j.jbusvent.2009.07.003

Port of Rotterdam Authority (2011), Port Vision 2030 - Port Compass: Direct the future. Start today, Port of Rotterdam Authority, Rotterdam.

Ries, E. (2011), The Lean Start-up: How Constant Innovation Creates Radically Successful Businesses, Penguin Books Limited, New York.

Ries, E. (2017), The Start-up Way: how modern companies use entrepreneurial management to transform culture and drive long-term growth, Currency, New York.

Shane, S. (2012), "Reflections on The 2010 AMR Decade Award: Delivering On The Promise of Entrepreneurship as a Field of Research", Academy of Management Review, Vol. 37 No. 1, pp. 10-20. https://doi.org/10.5465/amr.2011.0078

Smith, W.K. and Lewis, M.W. (2011), "Toward a Theory of Paradox: A Dynamic equilibrium Model of Organizing", Academy of Management Review, Vol. 36 No. 2, pp. 381-403. https://doi.org/10.5465/amr.2009.0223

Smith, W.K. and Tushman, M.L. (2005), "Managing Strategic Contradictions: A Top Management Model for Managing Innovation Streams", Organization Science, Vol. 16 No. 5, pp. 522-536. https://doi.org/10.1287/orsc.1050.0134

Strauss, A. and Corbin, J.M. (1990), Basics of qualitative research: Grounded theory procedures and techniques, Sage Publications, Thousand Oaks.

Tushman, M.L., Smith, W.K. and Binns, A. (2011), The Amdidextrous CEO. [online] Harvard Business Review. Available at: https://hbr.org/2011/06/the-ambidextrous-ceo

Vanhaverbeke, W. (2006), "The interorganizational context of open innovation", In: Chesbrough, H., Vanhaverbeke, W. and West, J. (Eds.), Open Innovation: Researching a New Paradigm, Oxford University Press, Oxford, pp. 205-219

Weiblen, T. and Chesbrough, H.W. (2015), "Engaging with Start-ups to Enhance Corporate Innovation", California Management Review, Vol. 57 No. 2, pp. 66-90. https://doi.org/10.1525/cmr.2015.57.2.66

West, J. and Gallagher, S. (2006), "Challenges of open innovation: the paradox of firm investment in open-source software”, R\&D Management, Vol. 36 No. 3, pp. 319-331. https://doi.org/10.1111/j.1467-9310.2006.00436.x

West, J. and Lakhani, K.R. (2008), "Getting clear about communities in open innovation", Industry and Innovation, Vol. 15 No. 2, pp. 223-231. https://doi.org/10.1080/13662710802033734

West, J., Salter, A., Vanhaverbeke, W. and Chesbrough, H. (2014), Open innovation: The next decade, Research Policy, Vol. 43 No. 5, pp. 805-811. https://doi.org/10.1016/j.respol.2014.03.001

Yin, R.K. (1994), Case study research: Design and Methods, Sage Publications, London.

Cristobal Garcia-Herrera, PhD Researcher

Imperial College London, Dyson School of Design Engineering \& Business School

10 Princess Gardens, SW7 2AZ London, United Kingdom

Email: c.garcia-herrera15@imperial.ac.uk 